\title{
Do Belief Differences Lead to Change in Behavior? A Study of Sri Lankan Coconut Farmers
}

\author{
C. S. Herath ${ }^{1}$
}

\begin{abstract}
Technology adoption by farmers is an important factor in agricultural development in both developing and developed countries that has not been achieved over the past years. The level of technology adoption is highly dependent on farmers' beliefs and attitudes. Therefore, adoption studies are important to identify beliefs and attitudes of farmers that affect decision making. The present study tries to explain and identify the effect of motivation on farmers' behavior to acquire knowledge and what are their beliefs and motives that underlie adoption of technology. The theory of planned behavior provides a structure to identify farmers' behavioral intention with respect to attitudes, subjective norms and perceived behavioral control. The Self Determination Theory provides an explanatory system for the understanding of the motivation behind volitional behavior. These two theories serve as the key methodology for the study. The results revealed that, farmers' participation in technology dissemination programmes and their willingness to gain information and skills have a significant relationship with intrinsic motivation. Further, those farmers hold positive beliefs towards new technology adoption and innovations. Therefore, two types of extension approaches are needed to enhance the technology adoption for intrinsically motivated and extrinsically motivated farmers.
\end{abstract}

Keywords: Farmer Field School, Farmers' behavior, Technology adoption

Jel Classification: I38; L29; Z13

\footnotetext{
${ }^{1}$ Technology Transfer Division, Coconut Research Institute, Lunuwila, Sri Lanka. Email: hmcsherath@yahoo.com
} 


\section{Introduction}

It is obvious that most of the world's developing countries are basically agriculture based and as a result, it has become one of the leading sources of employment which contributes to a greater extent in formation of the country's national income. Increasing agricultural productivity is critical to economic growth and development (Doss, 2006). The adoption of new innovations is often slow, even though profits are assured by new technologies. As a result, many of these countries agricultural productivity is extremely low. There is a challenge for agricultural researchers to understand how and when these technologies are used by farmers and with what impacts. For this task, agricultural scientists have turned to social scientists, asking for improved understanding of the mechanisms underlying technology adoption (Doss, 2006). Technology adoption process necessarily involves a social component. People have different behavioral patterns, social norms and sub cultures. Thereby the level of acceptability of new technologies highly depends on beliefs, norms and attitudes of the respective persons.

Technology adoption depends on farmers' behavioral change. There are many factors that determine individual's behavior. Understanding these factors is crucially important to increase the production and profits in farmland. Nevertheless, a few research studies only have explored farmers' beliefs and attitudes which contribute towards their decision making (Zubair and Garfoth, 2006). Research should go beyond the technical aspects of productivity improvements and should focus on human aspects to explore individual decisions on adoption of new technologies and accepting innovations.

Therefore, this study tries to explain and identify the effect of motivation on farmers' behavior in acquiring knowledge for technology adoption and what are their beliefs and motives that underlie such adoption.

\section{Theoretical framework}

\section{Theory of Planned Behavior (TPB)}

The Theory of Planned Behavior introduced by Ajzen (1991) explains that performance of a behavior is determined by the formation of an intention towards the behavior. In the TPB model, behavior is primarily predicted by someone's intention to perform that behavior, which in turn is predicted by individual attitudes (favorable or unfavorable) towards the behavior, other people's influences towards performing the behavior (subjective norm) and people feel they have control over the behavior (perceived behavioral control). The beliefs or information may be based on experience, fact, hearsay or may be fallacious. A farmer will weigh up all the influences on him from policy, advisory services, society, his family, friends, peers and the media. Based on all these influences and the information available, farmers form their beliefs. Figure 1 expresses the relationships of TPB.

\section{Motivation}

Motivation is the set of reasons that determines one to engage in a particular behavior. The motive is "internal tension" or "internal urge" that drives the human being to set himself a goal by means of the activity and to achieve it (Porvaznik and Coll, 2008).

Motivation can be categorized as either extrinsic motivation or intrinsic motivation. Intrinsic motivation is basically behaviour in a certain way for the enjoyment (McBride et al., 1994). According to McMurran (2002), intrinsic motivation is derived from values and beliefs, and it is mainly associated with greater long-term change. Conversely, extrinsic motivation is the motivation derived from the social environment (Petri, 1996) and it is associated with material and/or social rewards.

\section{Self Determination Theory (SDT)}

Self-determination theory is a key explanatory system for understanding the motivation behind volitional behaviors (Deci and Ryan, 1985). SDT basically identifies five categories of motivation levels based on the 
Figure 1. Theory of planned behavior according to Ajzen (1991)

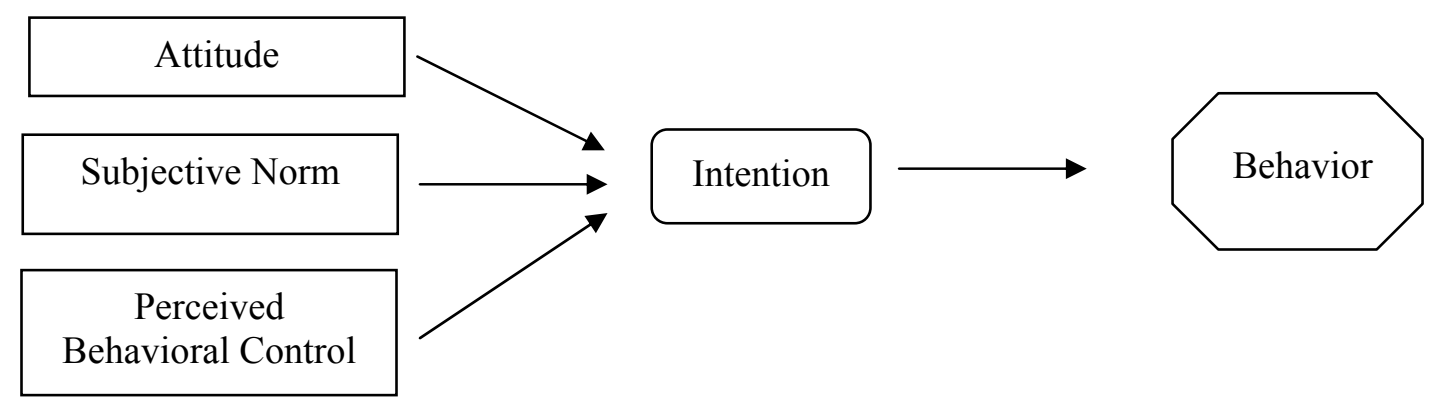

Table 1. Types of motivation according to the SDT

\begin{tabular}{|l|l|l|l|l|l|}
\hline $\begin{array}{l}\text { Type of } \\
\text { Motivation }\end{array}$ & A motivation & \multicolumn{3}{|c|}{ Extrinsic Motivation } & \multicolumn{1}{|c|}{$\begin{array}{c}\text { Intrinsic } \\
\text { Motivation }\end{array}$} \\
\hline $\begin{array}{l}\text { Type of } \\
\text { regulation }\end{array}$ & Non-regulation & $\begin{array}{l}\text { (1) External } \\
\text { regulation }\end{array}$ & $\begin{array}{l}\text { (2) Introjected } \\
\text { regulation }\end{array}$ & $\begin{array}{l}\text { (3) Identified } \\
\text { regulation }\end{array}$ & $\begin{array}{l}\text { Intrinsic } \\
\text { motivation }\end{array}$ \\
\hline $\begin{array}{l}\text { Perceived locus } \\
\text { of causality }\end{array}$ & Impersonal & External & $\begin{array}{l}\text { Somewhat } \\
\text { External }\end{array}$ & $\begin{array}{l}\text { Somewhat } \\
\text { Internal }\end{array}$ & Internal \\
\hline $\begin{array}{l}\text { Quality of } \\
\text { Behavior }\end{array}$ & $\begin{array}{l}\text { Non self determined } \\
\text { (Controlled) }\end{array}$ & \multicolumn{4}{|c|}{$\begin{array}{l}\text { Self determined } \\
\text { (Autonomous) }\end{array}$} \\
\hline
\end{tabular}

Source: Ryan and Deci (2000)

degree to which motivation originates from the self. These categories range from a motivation, three categories of extrinsic motivation and intrinsic motivation (Ryan and Deci, 2000).

\section{Methodology}

\section{Eliciting salient beliefs}

Attitude, subjective norm and perceived behavioral control are developed in a person by his salient beliefs towards the expected behavior. Salient beliefs are those that initially generate in the mind of a person when respondents are asked questions such as "Why do you think that would be advantageous for you to perform a certain behavior?" The salient beliefs in a given population can be identified by conducting an elicitation study in a representative sample of the population (Francis et al., 2004). The salient beliefs for the present study were identified by a survey conducted in Kurunegala district of Sri Lanka by randomly selecting 94 coconut farmers from two villages, during the months of March and April 2009. Seven, four and eight salient beliefs were identified for the attitude, subjective norm and perceived behavioral control respectively as the final set of salient beliefs for the present study.

\section{Measuring variables of TPB}

Attitude is computed by summing the products of the strength of beliefs about the perceived consequences of performing a behavior and an evaluation of those consequences (Stubenitsky and Mela 2000). The Subjective norm is measured by summing the products of normative belief and motivation to comply with the opinion of important others. Perceived behavioral control is calculated as the summated products of control beliefs (the perception of hindrances towards the adoption of new technology) and power of control beliefs (perceived influence of each factor on the individual's control over adoption of new technology) (Ajzen 1991). 
According to the concept of TPB, the overall model of TPB becomes,

$\mathrm{AB} \approx \mathrm{BI} \propto \mathrm{AT}+\mathrm{SN}+\mathrm{PBC}$

Where,

$\mathrm{AB}=$ Actual behavior, $\mathrm{BI}=$ Behavioral intension, $\mathrm{AT}=$ Attitude, $\mathrm{SN}=$ Subjective norm, $\mathrm{PBC}=$ Perceived behavioral control, $\mathrm{bb}=$ Behavioral belief strength, $\mathrm{oe}=$ Outcome evaluation, $\mathrm{nb}=$ Normative belief strength, $\mathrm{mc}=$ Motivation to comply, $\mathrm{cb}=$ Control beliefs, $\mathrm{p}=$ Power.

When the elements in the variables applied to the model;

$\mathrm{AB} \approx \mathrm{BI} \propto \sum_{i=1}^{s} \mathrm{bb}_{\mathrm{i}} \mathrm{oe}_{\mathrm{i}}+\sum_{j=1}^{t} \mathrm{nb}_{\mathrm{j}} \mathrm{mc}_{\mathrm{j}}+\sum_{k=1}^{u} \mathrm{cb}_{\mathrm{k}} \mathrm{p}_{\mathrm{k}}$

\section{Measuring variables of SDT}

Ryan and Connell (1989), developed an instrument "Relative Autonomy Index" to assessing behavioral regulations in the academic domain. The RAI is computed as follows, and represents a relative level of autonomous motivation, such that positive scores indicate stronger autonomous motivation and negative scores represent stronger controlled motivation.

RAI $=2$ (Intrinsic) +1 (Identified $)-$ 1(Introjected) - 2(External)

\section{Developing the survey instrument}

A structured questionnaire was used to collect data from the coconut farmers. Questions related to TPB and SDT were assessed based on a five point Likert scale representing five views ranging from "Strongly disagree to Strongly agree", "Extremely bad to Extremely good", "Not at all to Very much" and "Much more difficult to Much easier" where it appropriate. Each respondent was asked to assess individual perception based on a five-point semantic scale representing five views. The questionnaire was pre-tested with eight farmers. Francis et al, (2004) have suggested that a pre-test of 5-10 representative respondents is usually sufficient to identify problems with a questionnaire.

\section{Sampling method and data collection}

The sample for the research represented the farmers who are engaged in coconut cultivation in Sri Lanka. There was a farmer participatory technology transfer programme called "Farmer Field School" (FFS) which was implemented in Sri Lanka during 2006 to 2008. Basically, this programme introduced new pest management methods to farmers who cultivate coconut. This programme has been utilized for the present study to assess the farmers' beliefs and differences in technology adoption.

Farmer Field School programme (FFS) was implemented in five districts of Sri Lanka. Out of five districts, Kurunegala district was selected purposely for the study, because many FFS programmes were implemented in that district. Stratified simple random sampling method was applied to collect data. Two strata have been identified as the farmers who have participated at FFS (FFS) and the farmers who have not participated at FFS (NFFS). Kline (1994) mentioned that if the data is clear, sample of 100 is quite sufficient. According to Francis et al., (2004) for TPB studies, generally a sample size of 80 would be acceptable. The sample size for the study was 122 farmers. The sample frame for the farmers who have not participated at FFS was obtained from the "Grama Niladari" (Village Headman) of each village and the sample frame for the farmers who have participated at FFS was taken from the Coconut Research Institute of Sri Lanka.

The empirical research was carried out in Kurunegala district of Sri Lanka from May, 2009 to July, 2009. Random selection was done to collect data from two groups. Accordingly, data was collected from 61 farmers who have participated in the FFS and from another 61 farmers who have not participated in the FFS. Both samples were selected from the two villages where FFS was conducted. Data analysis was done by Chi-square test of independence and Mann-Whitney $U$ test using SPSS. 


\section{Results and Discussion}

\section{Reliability analysis}

Some concepts or constructs are not perfectly measured by a single item. Reliability analysis was conducted to ensure that the measured concepts were adequate or reliable (Hair et al 1998). Cronbach's alpha coefficient, measure of internal consistency, was used to estimate the reliability of the survey questionnaire. Table 2 presents the Cronbach's alpha for the TPB and SDT variables calculated by reliability analysis in SPSS.

Table 2. Cronbach' $s$ alphas of the variables in the model

\begin{tabular}{|c|l|c|}
\hline Variable & \multicolumn{1}{|c|}{ Description } & $\begin{array}{c}\text { Cronbach's } \\
\text { alpha }\end{array}$ \\
\hline $\mathrm{bb}$ & Behavioral beliefs & 0.799 \\
\hline $\mathrm{oe}$ & Outcome evaluation & 0.877 \\
\hline $\mathrm{nb}$ & Normative beliefs & 0.729 \\
\hline $\mathrm{mc}$ & Motivation to comply & 0.751 \\
\hline $\mathrm{cb}$ & Control beliefs & 0.751 \\
\hline $\mathrm{p}$ & Power of control beliefs & 0.671 \\
\hline $\mathrm{IR}$ & Introjection regulation & 0.709 \\
\hline $\mathrm{IDR}$ & Identification regulation & 0.821 \\
\hline
\end{tabular}

Source: Survey data, 2009

\section{First research problem}

Is there a significant relationship between farmers' participation in FFS programme and types of motivation?

\section{Hypothesis $\left(\mathrm{H}_{\mathrm{A}}\right)$}

There will be a relationship between farmers' participation in FFS programme and intrinsic motivation.

\section{Interpretation of first research problem}

Farmer Field School programme has been utilized in the study to investigate the relationship of farmer participation in such programmes and types of motivation.

Self Determination Theory was utilized to identify farmers who are intrinsically motivated and farmers who are extrinsically motivated.
"Relative Autonomy Index" split the total sample (122 respondents) into two groups. Autonomy group (Intrinsically motivated) comprises 54 respondents while controlled group (Extrinsically motivated) has 68 respondents.

Chi-square test of independence shows the relationship between FFS participation and types of motivation (Table 4). It could be seen that the $\mathrm{X}^{2}$ value of 53.15 , with one degree of freedom, is significant at $\mathrm{P}<0.001$. Hence, alternative hypothesis is accepted. In other words, the farmer participation in FFS programme has a relationship with intrinsic motivation. The strength of the relationship between variables was measured by Phi correlation and Cramer's V test (SPSS tutorial - Chi square test, online). These tests were used as post-test to determine strengths of associations after Chi-square test shows the significance.

Table 5 shows that Phi value, Cramer's V value and Contingency Coefficient are more than 0.5. Hence, it can be concluded that FFS participation and intrinsic motivation has a strong relationship.

\section{Second research problem}

Is there a significant difference between beliefs for new technology adoption of farmers who have participated at FFS programme (FFS) and who have not participated at FFS (NFFS)?

\section{Alternative hypothesis $\left(\mathrm{H}_{\mathrm{A}}\right)$}

There will be a difference between FFS and NFFS farmers in their beliefs that underlie decisions for new technology adoption.

\section{Interpretation of second research problem}

Second research problem was developed to study the differences in beliefs of farmers who have participated at FFS programme and those who have not participated. By investigating relevant salient beliefs, it indicates the mental (cognitive) differences between two farmer groups, those who were willing to get information on new technologies and those who were not. Mann-Whitney U test was employed 
Table 3. Contingency table of FFS participation and behavioral regulation

\begin{tabular}{|l|c|c|c|}
\hline & FFS farmers (\%) & Non-FFS farmers (\%) & Total \\
\hline Autonomous group & $47(77 \%)$ & $7(11 \%)$ & 54 \\
\hline Controlled group & $14(23 \%)$ & $54(89 \%)$ & 68 \\
\hline Total & $61(100 \%)$ & $61(100 \%)$ & 122 \\
\hline
\end{tabular}

Source: Survey data, 2009

Table 4. Chi-square test for FFS participation and behavioral regulation

\begin{tabular}{|l|c|c|c|c|c|}
\hline & Value & df & $\begin{array}{c}\text { Asymp. Sig. } \\
\text { (2-sided) }\end{array}$ & $\begin{array}{c}\text { Exact. Sig. } \\
\text { (2-sided) }\end{array}$ & $\begin{array}{c}\text { Exact. Sig. } \\
\text { (1-sided) }\end{array}$ \\
\hline Pearson Chi-Square & $53.159^{\mathrm{a}}$ & 1 & .000 & & \\
\hline Continuity Correction $^{\mathrm{b}}$ & 50.534 & 1 & .000 & & \\
\hline Likelihood Ratio & 58.325 & 1 & .000 & & .000 \\
\hline Fisher's Exact Test & & & & & .000 \\
\hline N of Valid Cases & 122 & & & & \\
\hline
\end{tabular}

${ }^{a} 0$ cells (0\%) have expected count less than 5 . The minimum expected count is 27.

${ }^{b}$ Computed only for a $2 \times 2$ table

Source: Survey data, 2009

Table 5. Phi correlations and Cramer's V test

\begin{tabular}{|l|c|c|}
\hline & Value & Approx. Sig \\
\hline Phi & .660 & .000 \\
\hline Cramer's V & .660 & .000 \\
\hline Contingency Coefficient & .551 & .000 \\
\hline N of Valid Cases & 122 & \\
\hline
\end{tabular}

Source: Survey data, 2009

to analyze the differences in beliefs between the two groups.

\section{Beliefs lead to develop attitude}

When examining median and interquartile range (IQR) values of both groups, FFS group has relatively higher median and interquartile range values on all three categories namely; behavioral belief, outcome evaluation and their summed product representing attitude (Table 6). The two groups are significantly different in six out of seven salient beliefs regarding the behavioral belief they hold. The behavioral belief that has not been significant between two groups was "New technologies reduce cultivation cost". In the outcome evaluation, all seven evaluative beliefs were significantly different between two groups. Regarding the summed product representing attitude, six out of seven salient beliefs were significantly different between two groups. "New technology reduces cultivation cost" was not significant between two groups. Further, the median value of total attitude of the FFS group was higher than NFFS group (median $=131, \mathrm{P}<$ 0.001) which indicated, that FFS group has stronger attitudes towards new technology adoption. It is obvious, because the information about Farmer Field School programme was spread in the village evenly and commonly. But some farmers have participated in the programme while some have not participated in 
the programme. This difference of interest and participation was due to their belief differences in new technology adoption.

However, both groups evaluated their salient beliefs in a positive manner. The median values were skewed towards positive attitude. Therefore, it indicated that even though farmers of FFS group have stronger attitudes than farmers of NFFS group, most of the farmers in these villages have relatively higher attitude towards new technology adoption.

\section{Beliefs lead to develop subjective norm}

The median and interquartile range (IQR) values of both groups showed how social pressure was created by the important persons that influence farmers' decision making. The relatively greater social pressure has been created for NFFS group for new technology adoption regarding normative belief, motivation to comply and their summed product representing subjective norm (Table 7).

The interesting feature in this category is, even though some salient beliefs showed statistically non significant, overall value statistically demarcate these two groups separately. It indicated that NFFS farmers perceived greater social pressure from the persons who are important to them (median $=$ 43, $\mathrm{P}<0.05)$. Thereby NFFS farmers have greater motivation than FFS farmers to comply with their views or suggestions on new technology adoption in their farmland. Further, it showed that FFS farmers have autonomy of farming decision making. They like to perform their farming decisions on their own beliefs than other person's suggestions.

Comparison of the median and interquartile range scores for subjective norm showed that NFFS farmers have relatively strong social pressure than FFS farmers in "my family", "my neighbor farmers" and "members of farmer organization". However, interquartile range shows the dispersion of median value, that social pressure created by "extension officer" was relatively stronger in FFS group than NFFS $(16-18)>(12-16)$. Probably it was because FFS group has more contacts with extension officer and believes him on their farmland advisory process. However, the social pressure created by "extension officer" does not have statistically significant difference between two groups. As a result, pressure could be created by the extension officer for both groups.

When considering the social pressure created by "my family", both groups have shown equal median values but the interquartile range shows the dispersion of median value. It was NFFS > FFS (9-16) > (6-16). But two groups have not shown statistically significant difference from each other. Therefore, family pressure for adopting new technology also could apply evenly to both groups. Farmer relationship with his/her spouse and children created a pressure without any difference to both groups. But NFFS farmers consider it as more important than FFS farmers.

In contrast, social pressure created by "my neighbor farmers" and "members of farmer organization" have relatively lower value in both groups. However, NFFS group believe stronger than FFS group on "my neighbor farmers" (median $=6, \mathrm{P}<0.001$ ) and "members of farmers organization" (median $=$ $6, \mathrm{P}<0.01$ ). However, both groups evaluated the salient beliefs of "my neighbor farmers" and "members of farmer organization" in negative manner. The median values were skewed towards negative side. Therefore, it indicated that both "my neighbor farmers" and "members of farmer organization" have very less impact on intention development for both groups. The median values of "my family" and "extension officer" were skewed towards positive side. Therefore, "my family" and "extension officer" could be identified as the key persons to motivate farmers in Sri Lankan coconut farming community.

\section{Beliefs lead to develop perceived behavioral control}

Farmers generally believe that there are factors that prevent or facilitate new technology adoption and thereby make them easy or difficult to practice. Perceived behavioral control is the category (variable) that assesses the farmers' ability to cope with barriers in 
Table 6. Comparison of the behavioral belief, outcome evaluation and attitudes of participants at FFS (FFS) and non-participants at FFS (NFFS)

\begin{tabular}{|c|c|c|c|c|c|c|c|c|c|}
\hline \multirow[b]{2}{*}{ Belief statements } & \multicolumn{3}{|c|}{ Behavioral belief (bb) } & \multicolumn{3}{|c|}{ Outcome evaluation (oe) } & \multicolumn{3}{|c|}{ Attitude (AT $=$ bb $*$ oe) } \\
\hline & $\begin{array}{c}\text { FFS } \\
\text { Median } \\
\text { (IQR) }\end{array}$ & $\begin{array}{c}\text { NFFS } \\
\text { Median } \\
\text { (IQR) }\end{array}$ & $\begin{array}{l}\text { Sig. }^{a} \\
(M-W)\end{array}$ & $\begin{array}{c}\text { FFS } \\
\text { Median } \\
\text { (IQR) }\end{array}$ & $\begin{array}{c}\text { NFFS } \\
\text { Median } \\
\text { (IQR) }\end{array}$ & $\begin{array}{l}\text { Sig. }^{a} \\
(\mathrm{M}-\mathrm{W})\end{array}$ & $\begin{array}{c}\text { FFS } \\
\text { Median } \\
\text { (IQR) }\end{array}$ & $\begin{array}{c}\text { NFFS } \\
\text { Median } \\
\text { (IQR) }\end{array}$ & $\begin{array}{l}\text { Sig. }^{a} \\
(M-W)\end{array}$ \\
\hline $\begin{array}{l}\text { New technologies, } \\
\text { achieve higher yield }\end{array}$ & $\begin{array}{c}5 \\
(4-5)\end{array}$ & $\begin{array}{c}4 \\
(4-4)\end{array}$ & .000 & $\begin{array}{c}5 \\
(4-5)\end{array}$ & $\begin{array}{c}4 \\
(4-5)\end{array}$ & .003 & $\begin{array}{c}20 \\
(16-25)\end{array}$ & $\begin{array}{c}16 \\
(15-20)\end{array}$ & .000 \\
\hline $\begin{array}{l}\text { New technologies, } \\
\text { increases income }\end{array}$ & $\begin{array}{c}4 \\
(4-5) \\
\end{array}$ & $\begin{array}{c}4 \\
(3-4)\end{array}$ & .000 & $\begin{array}{c}5 \\
(4-5)\end{array}$ & $\begin{array}{c}4 \\
(3-5)\end{array}$ & .002 & $\begin{array}{c}20 \\
(16-25)\end{array}$ & $\begin{array}{c}16 \\
(8-20)\end{array}$ & .000 \\
\hline $\begin{array}{l}\text { New technologies, } \\
\text { increases resource use } \\
\text { efficiency }\end{array}$ & $\begin{array}{c}4 \\
(4-5)\end{array}$ & $\begin{array}{c}3 \\
(2-4)\end{array}$ & .000 & $\begin{array}{c}5 \\
(4-5)\end{array}$ & $\begin{array}{c}3 \\
(2-4)\end{array}$ & .000 & $\begin{array}{c}20 \\
(15-25)\end{array}$ & $\begin{array}{c}9 \\
(4-16)\end{array}$ & .000 \\
\hline $\begin{array}{l}\text { New technologies, } \\
\text { achieve prestige in the } \\
\text { village }\end{array}$ & $\begin{array}{c}4 \\
(3-5)\end{array}$ & $\begin{array}{c}4 \\
(2-4)\end{array}$ & .045 & $\begin{array}{c}4 \\
(3-5)\end{array}$ & $\begin{array}{c}4 \\
(2-4)\end{array}$ & .013 & $\begin{array}{c}16 \\
(10-20)\end{array}$ & $\begin{array}{c}12 \\
(6-16)\end{array}$ & .006 \\
\hline $\begin{array}{l}\text { New technologies, cost- } \\
\text { effective }\end{array}$ & $\begin{array}{c}4 \\
(3-5) \\
\end{array}$ & $\begin{array}{c}4 \\
(3-4) \\
\end{array}$ & .018 & $\begin{array}{c}5 \\
(3-5)\end{array}$ & $\begin{array}{c}4 \\
(3-5)\end{array}$ & .019 & $\begin{array}{c}16 \\
(10-25) \\
\end{array}$ & $\begin{array}{c}12 \\
(8-18)\end{array}$ & .001 \\
\hline $\begin{array}{l}\text { New technologies, reduce } \\
\text { cultivation cost }\end{array}$ & $\begin{array}{c}3 \\
(2-4) \\
\end{array}$ & $\begin{array}{c}2 \\
(2-4) \\
\end{array}$ & .251 & $\begin{array}{c}5 \\
(4-5) \\
\end{array}$ & $\begin{array}{c}4 \\
(3-5) \\
\end{array}$ & .012 & $\begin{array}{c}10 \\
(5-20)\end{array}$ & $\begin{array}{c}10 \\
(10-16) \\
\end{array}$ & .080 \\
\hline $\begin{array}{l}\text { New technologies reduce } \\
\text { risk in cultivation }\end{array}$ & $\begin{array}{c}4 \\
(3-5) \\
\end{array}$ & $\begin{array}{c}3 \\
(2-4) \\
\end{array}$ & .000 & $\begin{array}{c}5 \\
(4-5) \\
\end{array}$ & $\begin{array}{c}4 \\
(3-5) \\
\end{array}$ & .024 & $\begin{array}{c}20 \\
(10-25) \\
\end{array}$ & $\begin{array}{c}12 \\
(5-16) \\
\end{array}$ & .000 \\
\hline$\sum \mathrm{bb}^{*} \mathrm{oe}$ & & & & & & & $\begin{array}{c}131 \\
(108-150)\end{array}$ & $\begin{array}{c}91 \\
(73-112)\end{array}$ & .000 \\
\hline
\end{tabular}

${ }^{a}$ Sig. $(M-W)=$ The Mann-Whitney U Test

Source: Survey data, 2009 
Table 7. Comparison of the normative beliefs, motivation to comply and subjective norm of participants at FFS (FFS) and non-participants at FFS (NFFS)

\begin{tabular}{|c|c|c|c|c|c|c|c|c|c|}
\hline \multirow[b]{2}{*}{ Belief statements } & \multicolumn{3}{|c|}{ Normative beliefs (nb) } & \multicolumn{3}{|c|}{ Motivation to comply (mc) } & \multicolumn{3}{|c|}{ Subjective norm $(\mathrm{SN}=\mathrm{nb} * \mathrm{mc})$} \\
\hline & $\begin{array}{c}\text { FFS } \\
\text { Median } \\
\text { (IQR) }\end{array}$ & $\begin{array}{c}\text { NFFS } \\
\text { Median } \\
\text { (IQR) }\end{array}$ & $\begin{array}{l}\text { Sig. }^{\mathrm{a}} \\
\text { (M-W) }\end{array}$ & $\begin{array}{c}\text { FFS } \\
\text { Median } \\
\text { (IQR) }\end{array}$ & $\begin{array}{c}\text { NFFS } \\
\text { Median } \\
\text { (IQR) }\end{array}$ & $\begin{array}{l}\text { Sig. }^{a} \\
(M-W)\end{array}$ & $\begin{array}{c}\text { FFS } \\
\text { Median } \\
\text { (IQR) }\end{array}$ & $\begin{array}{c}\text { NFFS } \\
\text { Median } \\
\text { (IQR) }\end{array}$ & $\begin{array}{l}\text { Sig. }^{a} \\
\text { (M-W) }\end{array}$ \\
\hline My family & $\begin{array}{c}4 \\
(2-4) \\
\end{array}$ & $\begin{array}{c}4 \\
(3-4)\end{array}$ & 0.160 & $\begin{array}{c}3 \\
(2-4)\end{array}$ & $\begin{array}{c}3 \\
(3-4)\end{array}$ & 0.228 & $\begin{array}{c}12 \\
(6-16)\end{array}$ & $\begin{array}{c}12 \\
(9-16)\end{array}$ & 0.212 \\
\hline $\begin{array}{l}\text { Extension Officer in } \\
\text { the area }\end{array}$ & $\begin{array}{c}4 \\
(3-4)\end{array}$ & $\begin{array}{c}4 \\
(3-4) \\
\end{array}$ & 0.313 & $\begin{array}{c}4 \\
(3-4)\end{array}$ & $\begin{array}{c}4 \\
(3-4) \\
\end{array}$ & 0.654 & $\begin{array}{c}16 \\
(16-18)\end{array}$ & $\begin{array}{c}16 \\
(12-16)\end{array}$ & 0.672 \\
\hline My neighbor farmers & $\begin{array}{c}2 \\
(1-3)\end{array}$ & $\begin{array}{c}3 \\
(2-3)\end{array}$ & 0.001 & $\begin{array}{c}2 \\
(1-2)\end{array}$ & $\begin{array}{c}2 \\
(2-3)\end{array}$ & 0.002 & $\begin{array}{c}4 \\
(1-6)\end{array}$ & $\begin{array}{c}6 \\
(4-9)\end{array}$ & 0.000 \\
\hline $\begin{array}{l}\text { Members of farmer } \\
\text { organization }\end{array}$ & $\begin{array}{c}2 \\
(1-3)\end{array}$ & $\begin{array}{c}3 \\
(2-4)\end{array}$ & 0.004 & $\begin{array}{c}2 \\
(1-2)\end{array}$ & $\begin{array}{c}2 \\
(2-4)\end{array}$ & 0.000 & $\begin{array}{c}4 \\
(1-6)\end{array}$ & $\begin{array}{c}6 \\
(2-16)\end{array}$ & 0.001 \\
\hline$\sum \mathrm{nb} * \mathrm{mc}$ & & & & & & & $\begin{array}{c}36 \\
(22-46)\end{array}$ & $\begin{array}{c}43 \\
(29-55)\end{array}$ & 0.019 \\
\hline
\end{tabular}

${ }^{a}$ Sig. $(M-W)=$ The Mann-Whitney U Test

Source: Survey data, 2009 
Table 8. Comparison of the control beliefs, power of control beliefs and perceived behavioral control of participants at FFS (FFS) and non-participants at FFS (NFFS)

\begin{tabular}{|c|c|c|c|c|c|c|c|c|c|}
\hline \multirow[b]{2}{*}{ Belief statements } & \multicolumn{3}{|c|}{ Control beliefs (cb) } & \multicolumn{3}{|c|}{ Power of Control beliefs (p) } & \multicolumn{3}{|c|}{ Perceived behavioral control $\left(\mathrm{PBC}=\mathrm{cb}^{*} \mathrm{p}\right)$} \\
\hline & $\begin{array}{c}\text { FFS } \\
\text { Median } \\
\text { (IQR) }\end{array}$ & $\begin{array}{c}\text { NFFS } \\
\text { Median } \\
\text { (IQR) }\end{array}$ & $\begin{array}{l}\text { Sig. }^{\mathrm{a}} \\
\text { (M-W) }\end{array}$ & $\begin{array}{c}\text { FFS } \\
\text { Median } \\
\text { (IQR) }\end{array}$ & $\begin{array}{c}\text { NFFS } \\
\text { Median } \\
\text { (IQR) }\end{array}$ & $\begin{array}{l}\text { Sig. }^{a} \\
(M-W)\end{array}$ & $\begin{array}{c}\text { FFS } \\
\text { Median } \\
\text { (IQR) }\end{array}$ & $\begin{array}{c}\text { NFFS } \\
\text { Median } \\
\text { (IQR) }\end{array}$ & $\begin{array}{l}\text { Sig. }^{\mathrm{a}} \\
(\mathrm{M}-\mathrm{W})\end{array}$ \\
\hline $\begin{array}{l}\text { *Technical assistance and } \\
\text { advisory is useful }\end{array}$ & $\begin{array}{c}4 \\
(3-5)\end{array}$ & $\begin{array}{c}2 \\
(1-2)\end{array}$ & 0.000 & $\begin{array}{c}4 \\
(3-4)\end{array}$ & $\begin{array}{c}3 \\
(2-4)\end{array}$ & 0.000 & $\begin{array}{c}16 \\
(9-20)\end{array}$ & $\begin{array}{c}4 \\
(3-8)\end{array}$ & 0.000 \\
\hline $\begin{array}{l}\text { *Purchasing inputs are } \\
\text { easy }\end{array}$ & $\begin{array}{c}3 \\
(2-4)\end{array}$ & $\begin{array}{c}2 \\
(1-2)\end{array}$ & 0.000 & $\begin{array}{c}3 \\
(2-3)\end{array}$ & $\begin{array}{c}2 \\
(2-4)\end{array}$ & 0.272 & $\begin{array}{c}6 \\
(4-12) \\
\end{array}$ & $\begin{array}{c}4 \\
(2-6)\end{array}$ & 0.000 \\
\hline $\begin{array}{l}\text { *Satisfied with output } \\
\text { price }\end{array}$ & $\begin{array}{c}3 \\
(2-4)\end{array}$ & $\begin{array}{c}2 \\
(2-3)\end{array}$ & 0.026 & $\begin{array}{c}3 \\
(2-3)\end{array}$ & $\begin{array}{c}3 \\
(2-3)\end{array}$ & 0.113 & $\begin{array}{c}9 \\
(4-12)\end{array}$ & $\begin{array}{c}6 \\
(2-8)\end{array}$ & 0.020 \\
\hline $\begin{array}{l}* \text { Farm labors are } \\
\text { available }\end{array}$ & $\begin{array}{c}3 \\
(2-4)\end{array}$ & $\begin{array}{c}2 \\
(1-2)\end{array}$ & 0.000 & $\begin{array}{c}3 \\
(2-4)\end{array}$ & $\begin{array}{c}3 \\
(2-3)\end{array}$ & 0.003 & $\begin{array}{c}9 \\
(6-15)\end{array}$ & $\begin{array}{c}4 \\
(2-7)\end{array}$ & 0.000 \\
\hline $\begin{array}{l}\text { *Improved technologies } \\
\text { are practicable at field } \\
\text { level }\end{array}$ & $\begin{array}{c}4 \\
(3-4)\end{array}$ & $\begin{array}{c}3 \\
(2-4)\end{array}$ & 0.000 & $\begin{array}{c}3 \\
(3-4)\end{array}$ & $\begin{array}{c}3 \\
(2-3)\end{array}$ & 0.001 & $\begin{array}{c}12 \\
(7-16)\end{array}$ & $\begin{array}{c}6 \\
(4-12)\end{array}$ & 0.000 \\
\hline $\begin{array}{l}\text { *Improved technologies } \\
\text { save time }\end{array}$ & $\begin{array}{c}3 \\
(2-4)\end{array}$ & $\begin{array}{c}2 \\
(1-4)\end{array}$ & 0.000 & $\begin{array}{c}3 \\
(2-3)\end{array}$ & $\begin{array}{c}2 \\
(1-3)\end{array}$ & 0.001 & $\begin{array}{c}9 \\
(6-13)\end{array}$ & $\begin{array}{c}4 \\
(2-9)\end{array}$ & 0.000 \\
\hline $\begin{array}{l}\text { *I trust on improved } \\
\text { technologies }\end{array}$ & $\begin{array}{c}4 \\
(3-5)\end{array}$ & $\begin{array}{c}2 \\
(2-3)\end{array}$ & 0.000 & $\begin{array}{c}3 \\
(3-4)\end{array}$ & $\begin{array}{c}3 \\
(2-3)\end{array}$ & 0.000 & $\begin{array}{c}15 \\
(9-16)\end{array}$ & $\begin{array}{c}6 \\
(4-9)\end{array}$ & 0.000 \\
\hline $\begin{array}{l}\text { *There are enough } \\
\text { subsidy programmes }\end{array}$ & $\begin{array}{c}3 \\
(2-3)\end{array}$ & $\begin{array}{c}2 \\
(1-3)\end{array}$ & 0.000 & $\begin{array}{c}5 \\
(4-5)\end{array}$ & $\begin{array}{c}5 \\
(4-5)\end{array}$ & 0.793 & $\begin{array}{c}12 \\
(9-15)\end{array}$ & $\begin{array}{c}6 \\
(5-12)\end{array}$ & 0.000 \\
\hline$\sum \mathrm{CB} * \mathrm{P}$ & & & & & & & $\begin{array}{c}87 \\
(75-102)\end{array}$ & $\begin{array}{c}49 \\
(37-65)\end{array}$ & 0.000 \\
\hline
\end{tabular}

${ }^{a}$ Sig. $(M-W)=$ The Mann-Whitney $U$ Test

*Belief statements have reversed only for control beliefs

Source: Survey data, 2009 
carrying out new technology in their farmlands. This category was evaluated in the questionnaire by negative statements or as a problem they would face in their new technology adoption decisions. It was because Francis et al., (2004) has mentioned that this category of questions have to be asked from respondents in a negative form. Further, other research studies also followed the same format (see Zubair and Garfoth, 2006 and Sambodi, 2007). But when presenting results, beliefs statements and scores have reversed to make it in a positive way for easy understanding. In addition, all the other belief statements were also presented in the positive way in other categories (attitude and subjective norm).

There were eight belief statements, which have been identified by the farmers in the elicitation study. These eight salient beliefs were tested in the final questionnaire. When it is compared with other two categories (attitude and subjective norm), farmers have given low scores to this category. It means, majority of farmers perceived that even though they have positive attitudes for adopting new technology, the external factors make hindrance to adopt new technology.

Table 8 shows the median and interquartile range (IQR) values of control belief, power and their summed product representing perceived behavioral control. The two groups differ significantly in all eight salient beliefs in perceived behavioral control. It clearly indicated that majority of FFS farmers' perception was that they can overcome the barriers and they were in optimistic view about new technology adoption. Their total median value was higher than NFFS farmers and it was $87, \mathrm{P}<0.001$. In contrast, NFFS farmers felt negatively about overcoming their hindrances. Their all median and interquartile range values show lesser magnitude than FFS farmers.

Even though FFS farmers assess stronger than NFFS farmers in their perceived behavioral control, one salient belief was assessed relatively negative by FFS farmers too. It was "purchasing inputs are easy" (median =
6) which showed that they have difficulties in purchasing inputs. It indicated that FFS farmers also feel economic barriers affect strongly for their new technology adoption decisions.

Above discussion highlighted that two groups were statistically different from each other in attitude, subjective norm and perceived behavioral control by performing MannWhitney $U$ Test. The results could be highlighted as median value of FFS group was higher than the median value of NFFS group $(131>91, \mathrm{P}<0.001)$ in attitude towards new technology adoption. Regarding subjective norm, the median value of NFFS was higher than the median value of FFS group (43 > 36, $\mathrm{P}<0.05)$. Therefore, NFFS group has greater social pressure for new technology adoption. The median value of FFS group for perceived behavioral control is higher than the median value of NFFS $(87>49, \mathrm{P}<0.001)$. These results imply that alternative hypothesis was accepted. That is, there are significant differences between FFS and NFFS groups in their beliefs that underlie decisions for new technology adoption.

\section{Conclusion}

This study was done to identify the effect of motivation on coconut farmers' technology adoption behavior and what are their salient beliefs underlying such adoption behavior. A farmer participatory technology transfer programme called Farmers Field School (FFS) was utilized to investigate the relationship of farmer participation in such programmes and types of motivation. According to the findings, participation in the Farmers Field School has a strong relationship with intrinsic motivation. It shows that there is a relationship for farmers' involvement in such programmes and their types of motivation. Farmers who are intrinsically motivated are always willing to devote their time and effort for such programmes. Thereby, they will gain information and skills first in the community and they will develop intention and perform the behavior, i.e. adopt new technology. In contrast, extrinsically motivated farmers take some time to get the information and skills, as they get 
these from their peer farmers and important persons. Hence, they will take some time to develop intention and perform the behavior. These findings coincide with Rogers's adoption innovation theory (Rogers, 1993). According to the theory, intrinsically motivated farmers are similar to innovators and early adopters while extrinsically motivated farmers belong to early majority and late majority category.

Next, the belief differences have been investigated among the farmers who have participated at the FFS and who have not. It indicates the mental difference between the two farmer groups, those who are willing to get information and those who are not. From the analysis, it could be concluded that FFS farmers were positively related with attitude and perceived behavioral control while they were negatively related with subjective norm. NFFS farmers were positively related with subjective norm and negatively related with attitude and perceived behavioral control. It indicated that intention of new technology adoption of FFS farmers can be motivated by developing favorable attitudes and reducing their barriers towards new technology adoption. Further, there was very much less impact from their important persons on their intention development. In contrast, NFFS farmers' intention development has a very strong relation with their important persons.

Lastly, it can be concluded that FFS and NFFS farmers belong to two different groups in their beliefs. Therefore, two types of extension approaches have to be applied to these two groups separately to enhance the level of adoption of new technology.

\section{References}

Ajzen, I., 1991. The theory of planned behavior. Organizational Behavior and Human Decision Processes, 50:179-211.

Deci, E. and Ryan, R., 1985. Intrinsic motivation and self-determination in human behavior. New York: Plenum.

Doss, C. R., 2006. Analyzing technology adoption using micro studies: limitations, challenges, and opportunities for improvement. Agricultural Economics, 34: 207-219.

Francis J.J., Eccles M.P, Johnston M., Walker A, Grimshaw J., Foy R., Kaner E.F.S., Smith L. \& Bonetti D., 2004. Constructing questionnaires based on the Theory of Planned behavior, A manual for health services researches, Centre for Health Services Research, University of Newcastle, 21 Claremont Place, Newcastle upon tyne, NE 24AA, United Kingdom.

Hair, J. F., Anderson, R. E. J., Tatham, R. L. and Black, W. C., 1998. Multivariate data analysis (5th ed.). New Jersey: Prentice-Hall.

Kline, P., 1994. An easy guide to factor analysis. London: Routledge.

Mcbride, C., Curry, S., Stephens, R., Wells, E., Roffman, R. and Hawkins, D., 1994. Intrinsic and extrinsic motivation for change in cigarette smokers, marijuana smokers, and cocaine users. Psychology of Addictive Behaviors, 8(4): 243-250.

Mcmurran, M., 2002. Motivation to change: Selection criterion or treatment need? In McMurran, M (ed). Motivating offenders to change. NY, NY: John Wiley and Sons: $3-13$.

Petri, H., 1996. Motivation: Theory, research, and applications. 4th ed. Pacific Grove, CA: Brooks Cole Publishing.

Porvaznik, J. and Coll., 2008. Holistic Management - Pillars of competence in Management. Slovak Academy of Management, IRIS, Bratislava.

Rogers, E. M., 1993. Diffusion of innovations (3rd ed.). New York: The Free Press.

Ryan, R. and Deci, E., 2000. Self-determination theory and the facilitation of intrinsic motivation, social development, and wellbeing. American Psychologist, 55(1): 6878 . 
Ryan, R. and Connell, J., 1989. Perceived locus of causality and internalization: Examining reasons for acting in two domains. Journal of Personality and Social Psychology. 57(5): 749-761.

Sambodo L.A.A.T., 2007. The decision making processes of Semi-commercial farmers: a case study of technology adoption in Indonesia, Unpublished Doctoral Thesis, Lincoln University, Canterbury, New Zealand.

SPSS Tutorial - Chi square test, [online], quot. 20 June 2010.

Stubenitsky K. and Mela D.J., 2000. UK consumer perceptions of starchy foods. British Journal of Nutrition, 83: 277-285.

Zubair, M. and Garforth, C., 2006. Farm level tree planting in Pakistan: the role of farmers' perceptions and attitudes. Journal of Agro forestry systems, 66: 217-229. 